\title{
SHODA PEDAGOGICKÉ NOMINACE A SKUPINOVÉHO TESTU INTELIGENCE PŘI SKRÍNINGU INTELEKTOVÉHO NADÁNÍ - SONDA DO PROBLEMATIKY
}

\author{
AGREEMENT BETWEEN TEACHER \\ NOMINATION AND GROUP-ADMINISTERED \\ INTELLIGENCE TESTING \\ IN THE PROCESS OF INTELLECTUAL \\ GIFTEDNESS SCREENING: \\ A PILOT STUDY
}

\author{
ŠÁRKA PORTEŠOVÁ, MICHAL JABƯREK, \\ MARTIN TANCOŠ, EDITA CHVOJKOVÁ, \\ SIMONA VÁLKOVÁ
}

\begin{abstract}
Abstrakt
Cílem studie je provést sondu do procesu skriningu intelektovébo nadáni zááki v běžné základni škole. Prédmètem této sondy je srovnat dva typy postupư pro identifikaci potenciálnè intelektově nadaných žákù

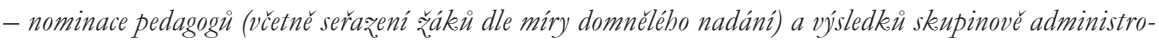
vanébo testu fuidní inteligence (CFT 20-R). Současnè byla žbodnocena délka praxe pedagogů jakožto faktoru, který může ovlivnovat souvislost nominace učitele a výsledku inteligenčníbo testu. Výžumu se zúčastnilo 6 trídních učitelu vybrané základni školy, kteříposuzovali celkem 106 žákù ze čtvrtých a pátých tríd. Mira shody mezi obèma postupy je spiše nízká a neni ovlivnèna délkou praxe zapojených pedagogü. Byl však nalez̨en slabý vžtah mez̧i poradím vybraných žákủ stanoveným pedagogem v rámci nominace a fluidni inteligenci měrenou testem. Tato zjištèni a jejich možné príčiny jsou diskutovány společně s doporučeními pro dalši směrování v rámci identifik ace nadaných dètí a s ním souvisejicím vądéláváním pedagogü.
\end{abstract}

Klíčová slova

intelektově nadaní žáci, identifikace, učitelé, délka praxe, fuidní inteligence 


\begin{abstract}
The aim of this pilot study was to describe the process of screening children for intellectual giftedness in a Czech school. The main topic of this study was to compare two procedures for identifying gifted pupils: teacher nomination (including the ranking of children by their assumed level of giftedness) and the results of a groupadministered fluid intelligence test (CFT 20-R). In addition, the length of the teachers' experience was considered as a factor that might influence the relationship between teacher nominations and CFT 20-R results. The sample consisted of 6 form teachers from a selected primary school who evaluated 106 pupils from the 4th and 5 th grades. The level of agreement between the two procedures was quite low and was not influenced by the length of experience in our sample of teachers. However, our study found a weak relationship between the teachers' ranking of nominated pupils and the pupils' fluid intelligence as measured by the test. The discussion section of this paper examines these findings and gives possible recommendations for future directions regarding the identification of giftedness and related training of teachers.
\end{abstract}

\title{
Keywords
}

intellectually gifted pupils, identification, teachers, length of experience, fluid intelligence

\section{Teoretický úvod}

Vyhledávání žáků se vzdělávacími odlišnostmi je velmi důležité zejména $\mathrm{v}$ současnosti, kdy jsou $\mathrm{v}$ rámci inkluze na pedagogy kladeny požadavky individualizovat vzdělávání žáků s různou mírou vzdělávacích potřeb. Předpokladem úspěšného procesu individualizace je však samotná identifikace těchto potřeb. Jednou ze skupin, které česká legislativa jasně vymezuje, jsou žáci nadaní a mimořádně nadaní (vyhláška č. 27/2016 Sb.). V této souvislosti tedy stojí před pedagogy úkol nominovat či identifikovat tyto žáky, doporučit je k dalšímu podrobnému vyšetření do pedagogicko-psychologické poradny (PPP) a připravit pro ně adekvátní vzdělávací program, který by míru jejich nadání respektoval.

\section{Konceptualizace nadání, zejména intelektového}

Aby však bylo možné nadané žáky identifikovat, je nejdříve potřeba stanovit jednoznačná kritéria nadání, což je velmi komplikované. Žádná z definic tohoto konstruktu totiž není mezi odborníky zcela jednotně prúijímána, žádná není zcela vyčerpávající a mnohé jsou zatíženy nejednotností v chápání klíčových pojmů jako talent, nadání, vysoké schopnosti, potenciál apod. (např. Dočkal, 2016; Gagné, 2005; Machů, 2010; Sternberg \& Davidson, 2005). O problematičnosti procesu konceptualizace nadání svědčí mimo jiné i skutečnost, že je toto téma předmětem odborných diskusí již více než sto let (pro ucelený přehled viz např. Dai, 2018).

I když současné moderní teoretické koncepce definují nadání spíše jako multidimenzionální konstrukt, zahrnující jak intelektové, tak i mimointelektové faktory (Gagné, 2005; Mönks \& Katzko, 2005; Renzulli, 2005; Tannen- 
baum, 1986), většina definic vztahujících se k pedagogicko-psychologické diagnostice nadání upřednostňuje jako dominantní kritérium nadprůměrnou inteligenci. Tento pohled vnesl jako první do výzkumů a později i procesu identifikace nadání americký psycholog L. M. Terman (1925). Vysoká inteligence se obvykle chápe jako mentální aktivita zaměřená k cíli, spojená s efektivní schopností řešit problémy, s kritickým myšlením, efektivním abstraktním uvažováním a nadprůměrnou pamětí (Pfeiffer, 2001).

Daný pohled je v rámci praktické diagnostiky obvykle operacionalizován tak, že jako nadané jsou označovány děti, které dosáhly IQ 130 a výše v některém ze standardizovaných inteligenčních testů (inteligence je $\mathrm{v}$ takovém př́padě ztotožňována s obecným g-faktorem). Prostřednictvím nadprůměrného IQ definuje intelektové nadání i psychologický slovník Americké psychologické společnosti (VandenBos, 2007), kriteriální hodnota IQ se objevuje v legislativním zakotvení nadaných žáků v některých státech (např. $90 \%$ států USA ve vymezení nadání zahrnuje inteligenci; McClain \& Pfeiffer, 2012) a velmi často se nadání operacionalizuje v podobě vysokého IQ pro potřeby výzkumů (Dočkal, 2016). V české školní legislativě neexistuje žádná kriteriální hranice nadání v podobě dosaženého IQ, nicméně dokument Národního ústavu pro vzdělávání, zaměřený na doporučené standardní postupy při komplexní diagnostice mimořádného nadání zejména $\mathrm{v}$ PPP (Národní ústav pro vzdělávání [NÚV], 2018) určitá, byt’ ne legislativně zakotvená kritéria mimořádného nadání vymezuje ve shodě s výše uvedeným, tedy hodnotou IQ 130 a výše při zohlednění chyby měření1.

Ačkoli reflektujeme aktuální modely nadání, které poukazují na multidimenzionalitu tohoto konstruktu (např. Sternberg \& Kaufman, 2018) a souhlasíme s nutností identifikace nadaných dětí i v oblastech, jako je např. umění či sport, předmětem této studie je skríning intelektového nadání, a tím i jeho úzké vymezení.

1 Standard komplexní diagnostiky mimořádného (intelektového) nadání (NÚV, 2018) v tomto kontextu konkrétně uvádí:

„Výrazná akcelerace rozumových schopností se prokazuje splněním jednoho z kritérií A, B:

Kritérium A: V komplexním testu inteligence je vážený skór testovaného po zohlednění možné chyby měření alespoň $\mathrm{v}$ jedné ze složek rozumových schopností nebo $\mathrm{v}$ jednom z indexových skórů minimálně dvě směrodatné odchylky nad průměrem pro danou věkovou skupinu.

Kritérium B: Vážené skóry minimálně dvě směrodatné odchylky nad průměrem pro danou věkovou skupinu byly dosaženy v dílčích subtestech, které jsou při zohlednění celého profilu rozumových schopností nebo výjimečně i samostatně dobrými prediktory matematického, technického, př́rodovědného, jazykového nebo humanitního nadání. Opět je nutné zohlednit u těchto vážených skórů i možnou chybu měření.“ 


\section{Možnosti identifikace intelektového nadáni pedagogem}

Snaha o vymezení konstruktu nadání však není pouhou součástí teoretických debat badatelů vedených snahou najít jeho skutečnou podstatu. Pojetí nadání př́mo ovlivňuje praktickou diagnostiku, např. podobu konkrétních identifikačních nástrojů či povahu jednotlivých kroků, které jsou při vyhledávání nadaných realizovány. Obvykle je proces identifikace členěn minimálně na dva kroky, z nichž první je označován jako tzv. skríning. V rámci něho jsou plošně zadávány větším skupinám dětí (obvykle celým třídám) inteligenční testy a př́padně další diagnostické metody. Na základě skríningu pak menší skupinka žáků, splňující určitá předem stanovená kritéria (tzv. cut-off skór), postupuje do další fáze, ve které dochází ke komplexnějšíi (obvykle individuální) diagnostice schopností.

Pro realizaci skríningové fáze identifikačního procesu se jako ideální jeví školní prostředí, kde je možné plošně zmapovat potenciál všech žáků daného populačního ročníku. $V$ rámci školy jsou nejčastěji pro identifikaci nadaných využívány skupinově administrovatelné výkonové testy (National Association for Gifted Children, 2015).

Obvykle se jedná o nástroje měřící tzv. fluidní inteligenci, která je definována jako způsob usuzování induktivního či deduktivního rázu, který využíváme při setkání s relativně novými úkoly, jejichž řešení nemáme zautomatizované a u kterých se není možné primárně spolehnout na dříve naučené postupy či předchozí znalosti (napřs. Schneider \& McGrew, 2018). Dle řady autorů je právě fluidní inteligence klíčovou charakteristikou při identifikaci rozumově nadaných žáků, jelikož představuje kognitivní potenciál dítěte (Silverman, 2009). Někteří autoři ji dokonce ztotožňují s obecnou inteligencí, tedy tzv. g-faktorem (pro přehled viz např. Kvist \& Gustafsson, 2008).

Z hlediska frekvence jsou hned po výkonových testech při identifikaci nadání nejčastěji využívány identifikační strategie založené na posuzování pedagogem. Jedná se bud’ o prŕímou nominaci (pedagog označí daného žáka jako nadaného či nikoliv), nebo o tzv. nominační (prrípadně posuzovací) škály (viz např. Jabůrek, 2014). Účelem těchto škál je rozpoznat co nejpřesněji nadání žáků na základě vybraných tzv. typických pozorovatelných behaviorálních charakteristik, které pedagog u daných žáků hodnotí. V České republice jsou $\mathrm{k}$ dispozici pouze dva nástroje tohoto typu, které byly standardizovány na reprezentativním vzorku - IDENA (Hříbková et al., 2013) a Škála charakteristik nadání (Havigerová, 2013), která je adaptací zahraniční metody CGS (Silverman, 1993).

Jak je zřejmé z výše uvedeného, důraz na intelektové schopnosti při vymezení mimořádného nadání se projevuje i v rámci skríningového procesu, kdy jsou nejčastěji využívány inteligenční testy. Zajímavé však je, že důraz na rozumové schopnosti není záležitostí skríningu jen $\mathrm{v}$ situaci, kdy jsou 
používány výkonové metody. Situace je podobná i v př́padě strategií založených na posuzování pedagogem, a to především při použití přímé nominace, kdy je konceptualizace nadání výrazně závislá na učiteli. Ukazuje se totiž, že v tomto ohledu považují pedagogové za nejdůležitější ty charakteristiky žáka, které se vztahují ke školnímu výkonu. Např. ve studii Neumeisterové a kolegů (2007), kdy měli pedagogové volně popisovat znaky nadaného žáka, zmiňovali nejčastěji schopnosti jako „motivovat sám sebe k výkonu“, „pracovat a učit se samostatně“, ,, učit se rychleji a snadněji než ostatní“, „, nadprůměrně pracovat a chápat věci“" apod. $V$ př́padě podobně zaměřené německé studie (Endepohls-Ulpe \& Ruf, 2006) byly také akcentovány školní charakteristiky („,vynikající výsledky ve škole“), ale ještě více intelektové schopnosti („,ýborné rozumové chápáni““ či ,inteligence“ obecně).

Tento důraz na akademické a intelektové schopnosti se projevuje i při identifikaci nadaných pomocí posuzovacích škál (např. Benson \& Kranzler, 2017), které se mohou zaměřovat na více různých oblastí nadání, jako je např. kreativita či intelektové, akademické a umělecké schopnosti. Vysoké korelace v hodnocení jednotlivých dimenzí naznačují, že učitelé mohou mít při posuzování s rozlišováním těchto oblastí problémy. I v tomto př́padě se tedy ukazuje, že pedagogové při vyhledávání nadaných žáků obvykle neberou v úvahu multidimenzionální povahu nadání, ale při hodnocení žáka vychází z obecného dojmu, který je primárně založen na školním výkonu. Tento dojem pak ovlivňuje posuzování pedagoga i v ne zcela souvisejících oblastech (např. v uměleckých schopnostech či sociálních dovednostech). Někteři autoři v této souvislosti mluví o tzv. haló efektu (Rothenbusch et al., 2018). Vzhledem k tomu, že školní výkon do velké míry souvisí s inteligencí (např. Kaufman et al., 2012), může být posuzování pedagogů překvapivě založeno na velmi podobných charakteristikách žáka, které jsou měřeny pomocí inteligenčních testů.

Existuje celá řada výzkumů, které se zaměřují na míru souvislosti hodnocení intelektových schopností pedagoga s výsledky inteligenčních testů (např. Machts et al., 2016). Ve většině těchto výzkumů je přitom výsledek $\mathrm{v}$ testu brán jako objektivní kritérium intelektového nadání, se kterým se hodnocení pedagoga (at' už pomocí přímé nominace či s použitím posuzovací škály) ověruje. $Z$ tohoto důvodu se $v$ těchto výzkumech mluví o míře efektivity pedagogů $\mathrm{v}$ identifikaci nadaných žáků. V této oblasti přitom existují mezi badateli značné kontroverze již několik desetiletí. Typickým př́ḱladem je dnes již historická studie Pegnato a Birche (1959), kteř́i konstatují, že pedagogové naprosto selhávají při identifikaci žáků s IQ nad 130. Jejich práce byla následně frekventovaně citována zejména $\mathrm{v}$ kontextech, které podporují tvrzení, že pedagogové nejsou spolehlivými posuzovateli při identifikaci nadaných žáků (nap̌r. Gear, 1976; Jacobs, 1971). Závěry Pegnata 
a Birche (1959) byly nicméně později zpochybněny (Gagné, 1994) s tím, že tito autoři při analýzách nepoužívali vhodné statistické metody. Současně se objevovaly další studie (Rost \& Hanses, 1997), které nejsou v otázce přesnosti hodnocení pedagogy tak kritické. Upozorňují však na to, že mezi pedagogy existují v úspěšnosti při vyhledávání nadaných žáků a obecně $\mathrm{v}$ přesnosti hodnocení jejich schopností (tedy souvislosti s výsledky výkonových testů) poměrně velké interindividuální rozdíly (viz např. Machts et al., 2016; Südkamp et al., 2012).

Díky těmto a podobným výzkumným závěrům se do popředí výzkumného zájmu dostaly v minulých desetiletích zejména snahy odhalit, které faktory souvislost pedagogického hodnocení s výsledky testů určují nejvíce. Je možné, že každý učitel má vlastní implicitní teorii nadání, ze které při nominaci či hodnocení vychází. Bohužel se ukazuje, že tyto subjektivní koncepce hodnotitelů mohou být založeny na stereotypech a mylných předpokladech týkajících se pohlaví, rasy, vzhledu, nezvyklých zájmů, osobnostních vlastností apod., a to např. ve smyslu „nadaný je obvykle introvertní hubený chlapec s brýlemi, který se zajímá o dinosaury“ (napr. Baudson \& Preckel, 2016; Carman, 2011; Siegle, 2001; Siegle \& Powel, 2004). Současně se ukazuje, že vliv těchto zkreslení lze omezovat. Mezi nejčastějšími faktory, které se zdají být klíčové pro efektivní proces pedagogické identifikace nadaných žáků, je zmiňován samotný postoj učitele k nadání a k nadaným osobám (Gross, 1997), kontakt s nadanými žáky (Gagné, 1994; Portešová et al., 2008), absolvování speciálního vzdělávání v problematice nadání (Hansen \& Feldhusen, 1994; Johnson et al., 1995) či zácvik práce s identifikační škálou a typickými charakteristikami nadaných (Renzulli et al., 1997).

Ukazuje se tedy, že schopnost pedagogů identifikovat nadané žáky se může $\mathrm{v}$ čase měnit a zlepšovat. Současně platí, že pedagogové jsou v přesnosti posuzování schopností dětí zpravidla úspěšnější než rodiče. Tento závěr se potvrzuje nejen v zahraničních studiích (Acar et al., 2016), ale i ve výzkumech v České republice (Havigerová et al., 2013). Nejpravděpodobnějším vysvětlením je to, že se oproti rodičům pravidelně setkávají s větším množstvím dětí s rozdílnou úrovní schopností, a mají tedy lepší představu o normě. Tyto znalosti pak dokáží využít při hodnocení schopností a identifikaci nadaných žáků. Intuitivně se tedy nabízí hypotéza, že s rostoucí praxí pedagoga se bude také zpřesňovat jeho prredstava o normě a tím také jeho hodnocení, tedy bude docházet ke zvyšování souvislosti mezi hodnocením pedagoga a výsledků inteligenčního testu. Překvapivě se však ukazuje, že délka praxe neovlivňuje přesnost učitele při posuzování schopností žáků (Demaray \& Elliot, 1998; Impara \& Plake, 1998) a dokonce nemá ani vliv na jeho př́stup k nadaným (McCoach \& Siegle, 2007). 


\section{Zamèrení a cíle studie}

Výše uvedené studie zabývající se přesností pedagogů při identifikaci intelektového nadání však nejčastěji pracují s daty získanými od pedagogů různých škol, případně porovnávají efektivitu studentů pedagogiky a praktikujících pedagogů (Carman, 2011), čímž se ztrácí vliv celkového nastavení školy a jejího klimatu. Přičemž právě nastavení konkrétní školy může přímo ovlivňovat prosazovaný koncept nadání u jednotlivých pedagogů (Hunsaker, 1994) a formovat tak identifikační proces.

Vzhledem k tomu, že v české vyhlášce 27/2016 Sb. hraje právě škola při nominování a identifikaci nadaného žáka zásadní roli, snažíme se více do tohoto procesu proniknout. Cílem naší studie je provést sondu do procesu vyhledávání intelektově nadaných žáků $\mathrm{v}$ běžné české škole s větším počtem žáků. Náš výzkum je zaměřen na souvislost hodnocení učitele formou prosté nominace s výkonovým inteligenčním testem, obě metody výběru jsou však pojímány skríningově. Chceme tedy zjistit, do jaké míry se shodují závěry dvou odlišných skríningových postupů při identifikaci intelektově nadaných žákủ čtvrtých a pátých ročníků. Současně nás zajímá, zda souvislost obou postupů ovlivňuje délka praxe pedagogů.

I když si uvědomujeme, že proces identifikace rozumového nadání ve školním prostředí je velmi složitý a náš pohled je jen jeho určitým zjednodušením, přesto se domníváme, že i takto zaměřená sonda může přinést nové poznatky pro pedagogicko-psychologickou praxi i pro další výzkum.

Specificky je cílem studie odpovědět na následující výzkumné otázky:

VO1: Do jaké míry se shoduje označení žáků jako potenciálně intelektově nadaných $\mathrm{v}$ rámci skríningového procesu na základě výsledků v testu fluidní inteligence a pedagogické nominace?

VO2: Ovlivňuje míru této shody délka praxe pedagoga?

\section{Metoda}

\section{Výzkumný soubor}

Vzorek tvořili pedagogové a žáci čtvrtých a pátých tř́id jedné ze základních škol v okresním městě Olomouckého kraje. Škola je kapacitně velká - v současné době ji navštěvuje téměř 800 žáků, ve škole je 32 tř́íd a učí zde 56 pedagogů. Ředitelství školy má pozitivní postoj k vyhledávání a rozvoji nadaných žáků, považuje to za důležitou součást svého školního vzdělávacího programu. Nejde nicméně o školu, která by se tímto směrem cíleně profilovala. Žádný z pedagogů současně neabsolvoval speciální vzdělávání v problematice identifikace a vzdělávání nadaných žáků. 
Do výzkumu se zapojilo pět třídních učitelek a jeden tř́́dní učitel ze dvou čtvrtých a čtyř pátých tř́d. Tito pedagogové měli rozdílnou délku praxe, s průměrem 16,00 let $(S D=10,68)$. Konkrétní délka praxe byla u pedagoga A 15 let, pedagoga B 6 let, pedagoga C 28 let, pedagoga D 22 let, pedagoga E 1 rok a pedagoga F 24 let. Na základě informovaného souhlasu rodičů a dodržení podmínek GDPR i etiky se výzkumu zúčastnilo 106 dětí - 31 žáků (z toho 16 chlapců) ze čtvrtých a 75 žáků (z toho 22 chlapců) z pátých tříd. $\mathrm{V}$ době výzkumu byl průměrný věk žáků čtvrtých tříd 10,29 let $(\mathrm{SD}=0,35)$ a pátých tř́d 11,31 let $(\mathrm{SD}=0,33)$.

\section{CFT 20-R}

\section{Použité metody}

Test CFT 20-R (Fajmonová et al., 2015) je adaptací Cattellova neverbálního testu, který je určen $\mathrm{k}$ měření tzv. fluidní inteligence u dětí ve věku 7,5 až 15 let. Test se skládá ze 4 subtestů (princip sérií, princip klasifikace, princip matric a princip topologie), které jsou založeny na výběru obrazce z několika nabízených možností.

Test sestává ze dvou částí (obsahujících 56 a 45 položek). První část, kterou je možné administrovat samostatně, mủže být zadána se standardním či prodlouženým časovým limitem. V rámci výzkumu byla zadávána první část s prodlouženým časovým limitem. Reliabilita české verze testu, kterou uvádí autoři v manuálu, je dostatečně vysoká (koeficient vnitřní konzistence činí $r=0,88)$. Tato hodnota reliability byla použita i pro výpočet intervalu spolehlivosti.

\section{Výzkumný postup}

Abychom zvoleným výzkumným postupem co nejvíce napodobili skrínink pro vyhledávání intelektově nadaných žáků v prostředí jedné školy, postupovali jsme v souladu s oficiálními metodickými doporučeními určenými pro české pedagogy (Čavojská \& Šedá, 2010). Pedagogové proto byli požádáni, aby si představili hypotetickou situaci, kdy mají ze své třídy nominovat $\mathrm{k}$ dalšímu vyšetření $\mathrm{v}$ pedagogicko-psychologické poradně (PPP) ty žáky (počet jsme nechali na jejich uvážení), kteří by s větší pravděpodobností splnili kritérium intelektového nadání. Zároveň jim bylo řečeno, aby stanovili pořadí takto vybraných dětí dle míry jejich domnělého nadání. Někteří pedagogové určili pořadí striktně (na každé místo v řadě jedno dítě), někteř́ na stejnou pozici v nominační řadě umístili i více dětí zároveň.

Abychom zjistili míru shody mezi pedagogickou nominací a identifikací standardizovaným inteligenčním testem, zadali jsme test fluidní inteligence CFT 20-R následně vždy všem žákům (s informovaným souhlasem) v každé třídě, nikoli pouze těm, kteří byli nominovaní pedagogy. Tento postup nám umožnil lépe odpovědět na otázku míry shody (pedagog vs. standardizovaná 
metoda) a současně nám umožnil sledovat identifikační strategii každého pedagoga zvlášst' v kontextu jeho vlastní tř́dy. Po vyhodnocení testu jsme na základě skóru v CFT 20-R nominovali jako potenciálně nadané ty žáky, kteří dosáhli standardního skóru 130 a výše (při zohlednění intervalu spolehlivosti byla tato hranice stanovena na 124). Nakonec jsme posoudili, do jaké míry se shodují nominace, $\mathrm{k}$ nimž dospěli pedagogové, s těmi, které vzešly z výsledků standardizovaného testu.

Po skončení výzkumu jsme sdělili pedagogům všech tříd (pokud k tomu dali rodiče souhlas), kteř́ z jejich žáků by splnili kritérium intelektového nadání pomocí inteligenčního testu. Pedagogové tedy získali informaci o míře shody vlastní nominace a výsledku standardizované metody. Současně byli obeznámeni s možnými chybami měření i negativními vlivy, které mohly výsledky testování v některých ohledech zkreslit.

\section{Výsledky}

\section{Shoda identifikace nadáni pedagogem a standardizovaným testem inteligence} Jako první nás zajímala míra shody nominace pedagoga s nominací na základě výsledku v testu CFT 20-R. Vzhledem k nejednotnosti postupu pedagogů při určování pořadí (viz výzkumný postup) jsme $\mathrm{v}$ této části analýz pořadí dětí zanedbali a přistupovali k jednotlivým nominacím pouze binárně (nominovaný/nenominovaný).

Nejvíce intuitivní postup představuje vyjádření míry shody v absolutní míre (tedy jako počet dětí, které byly nominovány jak pedagogem, tak dle výsledků CFT 20-R). Tato míra však nijak nezohledňuje různou pravděpodobnost tzv. náhodné shody a zároveň znemožňuje korektní porovnání tříd mezi sebou.

Náhodnou shodou je v tomto kontextu míněno, že pravděpodobnost toho, že pedagogem nominované děti budou zároveň vybrány i inteligenčním testem, se liší dle počtu dětí, ze kterých pedagog vybírá a zároveň dle samotného počtu učitelem či testem nominovaných dětí. U větší tř́ídy tato pravděpodobnost klesá, u většího počtu nominovaných dětí pak roste. Tento vliv je však při posuzování „reálné“ míry shody nebo při porovnávání nežádoucí, a je tedy snaha jej statisticky korigovat.

Z tohoto důvodu jsme pro vyjádření shody použili jiný ukazatel, tzv. Cohenovu kappu $(x ; \text { Cohen, } 1960)^{2}$. Tento koeficient umožňuje zohlednit různý

2 Dle Cohena (1960) je koeficient kappa vyjádřen obecně touto rovnicí: $x=(\mathrm{p}(\mathrm{o})-\mathrm{p}(\mathrm{e}))$ / $(1-\mathrm{p}(\mathrm{e}))$, kde $\mathrm{p}(\mathrm{o})$ je pravděpodobnost (resp. podíl) pozorované shody a $\mathrm{p}(\mathrm{e}) \mathrm{je}$ pravděpodobnost předpokládané (tzn. zcela náhodné) shody. 
počet dětí i rozdílné počty nominací napřič třídami. Tuto výhodu má zejména díky vlastnosti, že považuje za shodné posouzení i př́pady, kdy oba skríningové postupy došly společně k závěru, že žáka jako potenciálně nadaného nenominují (tzv. true negative). Koeficient nabývá hodnot od -1 (úplná neshoda) do 1 (úplná shoda). Cohenovu kappu rovnou 0 tedy většinou lze interpretovat jako shodu v 50 \% př́padů - tedy výběr ekvivalentní např. hodu mincí.

Tabulka 1 shrnuje všechny zmíněné koeficienty za každou tř́du včetně počtu žáků ve tř́́dě, kteří se zapojili do studie. Z tabulky je zřejmé, že učitelé jsou v kritériích při nominaci žáků oproti CFT 20-R mnohem benevolentnější - z celkového počtu 106 žáků jich pedagogové za rozumově nadané označili 33, na základě výkonového testu jich bylo nominováno pouze 12, oproti učitelům tedy téměř třetina. Absolutní shoda mezi těmito formami skríningu je přitom poměrně malá - došlo $k$ ní jen v př́padě 6 žáků.

Tabulka 1

Prebled počtu nominovaných dètí v každé trídě a miry shody nominací.

\begin{tabular}{|l|c|c|c|c|c|c|}
\hline \multirow{2}{*}{ tř́da } & \multirow{2}{*}{$\begin{array}{c}\text { praxe } \\
\text { pedagoga }\end{array}$} & \multirow{2}{*}{$\begin{array}{c}\text { počet } \\
\text { žáků }\end{array}$} & \multicolumn{2}{|c|}{ počet nominovaných } & \multirow{2}{*}{$\begin{array}{c}\text { shodné } \\
\text { nominace }\end{array}$} & \multirow{2}{*}{$\begin{array}{c}\text { Cohenova } \\
x\end{array}$} \\
\cline { 5 - 6 } & pedagogem & CFT 20-R & & \\
\hline A & 15 let & 18 & 8 & 2 & 2 & 0,27 \\
\hline B & 6 let & 13 & 6 & 2 & 2 & 0,35 \\
\hline C & 28 let & 17 & 6 & 1 & 0 & $-0,11$ \\
\hline D & 22 let & 15 & 4 & 3 & 0 & $-0,29$ \\
\hline E & 1 rok & 22 & 5 & 2 & 1 & 0,18 \\
\hline F & 24 let & 21 & 4 & 2 & 1 & 0,24 \\
\hline
\end{tabular}

Pozn. „počet žákư“ zahrnuje pouze žáky zapojené do studie (s informovaným souhlasem rodičů).

\section{Mira fluidní inteligence žákư nominovaných pedagogem prí zoblednèni poradi nominace}

Mírně odlišný pohled na žáky nominované třídními učiteli, který zohledňuje pořadí nominace, poskytuje graf 1 . Zde jsou znázorněni všichni pedagogem nominovaní žáci dle tříd. Čísla označují jejich pořadí, ve kterém byli učitelem vybráni. Na vodorovné ose jsou body rozmístěny dle IQ skórů v testu inteligence včetně $95 \%$ intervalu spolehlivosti. Svislá tučná čára označuje hranici mimořádného nadání dle CFT 20-R, tedy hranici 130 bodů IQ. Kř́žžky označují ty děti ve tř́idě, které dle výsledků testu splňovaly kritérium mimořádného nadání, ale nebyly nominovány učitelem. 
Lze si povšimnout, že ve většině tříd nominoval třídní učitel alespoň jednoho žáka, který by dle CFT 20-R splňoval nejčastěji používanou definici rozumového nadání, tedy IQ větší než 130 (v našem případě bylo postačující podmínkou, aby se interval spolehlivosti IQ s touto hranicí překrýval). Ve trrídách $\mathrm{A}$ a $\mathrm{B}$ pedagog nominoval dva takové žáky, v třídách $\mathrm{E}$ a $\mathrm{F}$ pak po jednom žákovi.

Ve tř́idě $C$ sice pedagog nevybral žáka, který by splňoval definici nadání dle CFT 20-R, i tak lze ale považovat výběr žáků za relativně vhodný, nebot' všichni nominovaní se pohybují alespoň v pásmu nadprůměru a někteří žáci se hranici IQ 130 blíží. Na druhou stranu se v této tř́ídě vyskytuje dítě, které by podle inteligenčního testu bylo považováno za nadané, ale pedagog jej nenominoval.

Nejnižší shoda mezi nominací pedagoga a výsledkem testu je $\mathrm{v}$ případě trrídy $\mathrm{D}$. V tomto př́padě pedagog sice vybral děti, které se pohybují v pásmu nadprůměru, nenominoval však žádného ze tří žáků, kteří by jinak splňovali kritérium nadání dle CFT 20-R. Toto se projevilo i v nízkém koeficientu shody posouzení (Cohenova $x$ ).

Současně je třeba dodat, že i když ve třídách $\mathrm{A}, \mathrm{B}$ a F byly vybrány děti, které lze dle testu označit za nadané, byly společně s nimi nominovány i děti, které se pohybují ve fluidní inteligenci v pásmu průměru, ve vybraných případech dokonce i pod průměrem.

Dále jsme se zaměřili na to, zda pořadí přisouzené dětem trrídními učiteli nějakým zpo̊sobem reflektuje vztah s fluidní inteligencí určenou CFT 20-R. Zde jsme pro snadnějšś interpretaci sloučili hodnoty IQ a pořadí žáků všech tř́d. V takto definovaném souboru byl nalezen mírný vztah mezi pořadím a fluidní inteligencí (Kendallovo $\tau=-0,34 ; \mathrm{p}=0,01)^{3}$, který je statisticky významný. Tento vztah ukazuje, že s nižším (tedy lepším) pořadím přiřazeným pedagogem mírně roste žákova fluidní inteligence.

Kendalovo tau $(\tau)$ je jeden z korelačních koeficientů určených pro př́ípady, kdy je alespoň jedna z uvažovaných proměnných ordinální povahy (a je tedy porušen předpoklad pro použití koeficientů založených na momentových statistikách, nap̌r. nejčastěji používaného Pearsonova korelačního koeficientu). Podobně jako jiné korelační koeficienty nabývá hodnot od -1 do 1 . 

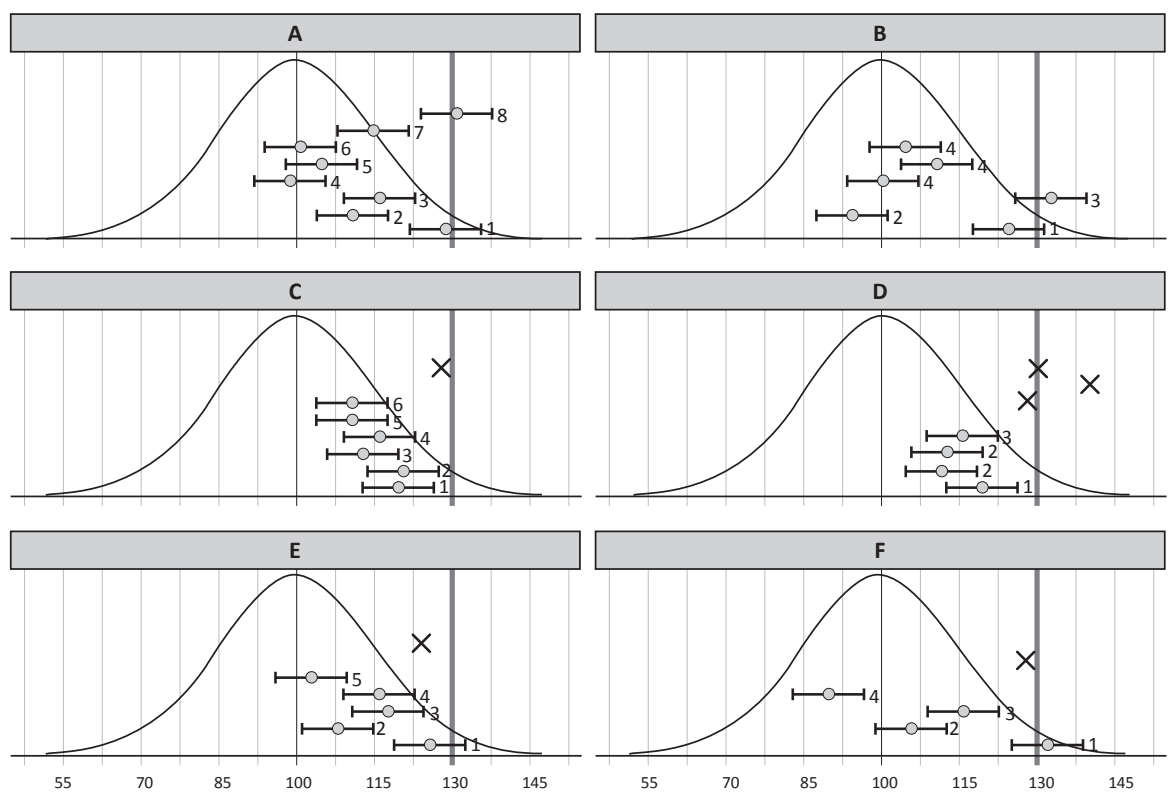

IQ

Graf 1

Fluidni inteligence nominovaných dètí pedagogy na základě CFT 20-R se zoblednèním pořadí výbèru v rámci jednotlivých tríd.

Pozn.: Č́sla vedle intervalů spolehlivosti představují pořadí žáků stanovené trúídním učitelem, kř́žky pak označují ty žáky, kteří by dle CFT 20-R byli označeni jako nadaní, ale učitel je nenominoval.

Tento vztah lze považovat za částečný důkaz toho, že fluidní inteligence žáků ovlivňuje to, zda bude žák nominován pedagogem jako rozumově nadaný. Z uvedené síly vztahu je však zřejmé, že se jedná pouze o jeden z faktorů, který pedagogovo hodnocení ovlivňuje. Jako argument podporující spíše malý vliv fluidní inteligence žáků při nominaci pedagogů může posloužit např. třída A, kdy za rozumově nadané dle CFT 20-R by byli označeni dva žáci, které pedagog umístil na první a zároveň poslední místo.

\section{Vliv délky praxe}

Na závěr nás zajímalo, zda není míra shody mezi nominací pedagoga a nástroje CFT 20-R ovlivněna délkou pedagogické praxe. Pro základní přehled je délka praxe jednotlivých pedagogů uvedena také v již zmíněné tabulce 1 . Vztah shody posouzení obou forem nominací s délkou praxe je přehledně znázorněn grafem 2 . 
Jak je patrné z grafu 2, mezi shodou posouzení a délkou praxe pedagogů nelze na úrovni tohoto konkrétního vzorku vypozorovat smysluplný lineární vztah. Nezdá se tedy, že by s větší či naopak menší délkou praxe rostla i shoda posouzení žáků jako potenciálně nadaných. S ohledem na malý vzorek pedagogů a dětí $\mathrm{v}$ naší studii však není možné uvažovat o zobecnění tohoto závěru na celou populaci pedagogů. Považujeme rovněž za nutné zmínit, že ani učitel s nejvyšší mírou Cohenovy $x$ nebyl v porovnání se svými kolegy v identifikaci nadaných dětí zásadně úspěšnější.

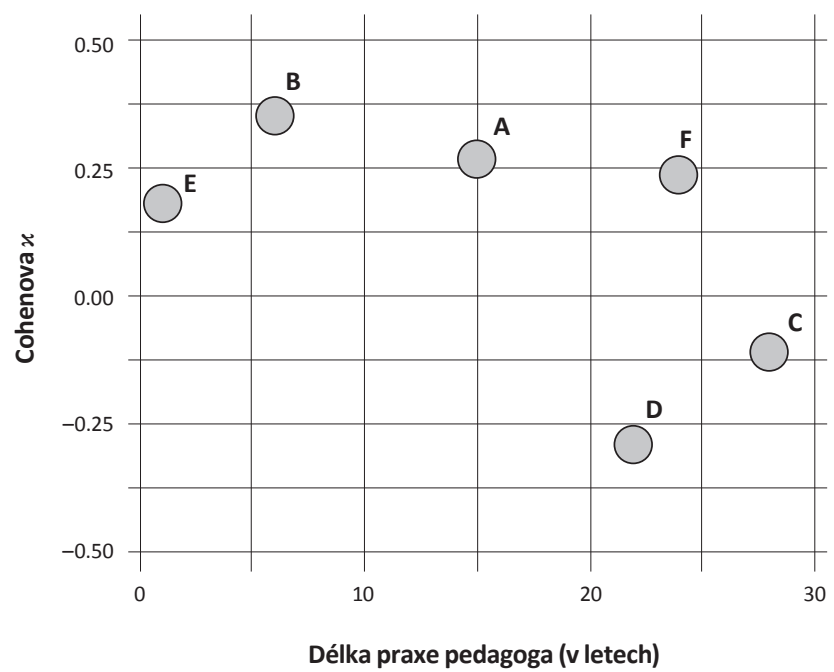

Graf 2

Shoda posonzení intelektového nadání ǎákì v souvislosti s délkou praxe učitele.

\section{Diskuse}

Jednou z největších výzev vzdělávání nadaných žáků je nominovat (k podrobné diagnostice nebo $\mathrm{k}$ zařazení do speciálních rozvojových programů) ty „opravdové“ nadané žáky (Worrell \& Erwin, 2011). Primárním zdrojem této nominace jsou ve většině př́padů u nás i v zahraničí učitelé a výsledky ve skupinově administrovaných testech inteligence (Freeman \& Josepsson, 2002; McClain \& Pfeiffer, 2012). Cílem našeho př́spěvku bylo provést pilotní sondu do procesu vyhledávání nadaných žáků $\mathrm{v}$ rámci jediné školy, kterou navštěvuje větší počet žáků, a zmapovat míru shody mezi těmito dvěma formami skríningu.

V rámci studie jsme dospěli k několika zajímavým výzkumným zjištěním. $\mathrm{S}$ ohledem na relativně malý výzkumný soubor sice není možné výsledky 
př́liš zobecňovat, nicméně se domníváme, že i ony mohou vést další výzkumníky $\mathrm{k}$ realizaci rozsáhlejších studií, které mohou naznačené trendy dále systematicky oveřrovat.

S ohledem na předchozí výzkumy (např. Endepohls-Ulpe \& Ruf, 2006; Neumeister et al., 2007), které naznačují, že pedagogové akcentují při definici mimořádného nadání školní výkon a inteligenci žákủ, jsme očekávali, že překryv mezi učitelskou a testovou nominací by mohl být poměrně značný. Vztah mezi těmito dvěma formami skríningu je však překvapivě poměrně slabý. Za intelektově nadané označili pedagogové 33 žáků, kritérium testu CFT 20-R jich splnilo 13. Ke shodě došlo pouze v př́ípadě 6 žáků. Naše původní př́edpoklady, že je nominace pedagoga ovlivněna fluidní inteligencí žáka, však do určité míry potvrzuje bližší analýza vztahu mezi těmito dvěma formami skríningu.

Ve chvíli, kdy k nominaci nepřistupujeme pouze binárně (tedy nominoval/ nenominoval), ale bereme $\mathrm{v}$ úvahu také pořadí nominovaných žáků, které stanovil pedagog dle předpokládané úrovně nadání, můžeme nalézt vztah tohoto pořadí se skórem $\mathrm{v}$ testu inteligence, který je však také poměrně slabý. Zdá se tedy, že učitelé a skupinově administrovaný test inteligence vybírají v rámci identifikačního procesu do velké míry jiné žáky a učitelovo hodnocení je žákovou úrovní fluidní inteligence ovlivněno jen mírně (což je v souladu se závěry výzkumů, které naznačují vliv dalších faktorů na nominaci, jako je např. pracovní pamět’ žáků, viz např. Kornmann et al., 2015).

Přitom právě výsledky $\mathrm{v}$ testech inteligence bývají nejčastěji v poradenské praxi považovány za objektivní kritérium mimořádného rozumového nadání. Je nutné podotknout, že se testy nejčastěji používané v PPP obvykle liší od nástroje CFT 20-R tím, že jsou administrovány individuálně a pokrývají více kognitivních schopností. Nicméně i u těchto testů je právě úroveň fluidní inteligence, kterou měří i námi použitý nástroj, při diagnostice nadání považována za klíčové kritérium. Pokud bychom si tedy dovolili myšlenkový experiment a nebrali test fluidní inteligence jako skríningový nástroj, ale jako objektivní kritérium mimořádného rozumového nadání, se kterým je porovnávána učitelská nominace, bylo by nutné hodnocení učitelů označit za poměrně nepřesné. Současně je zřejmé, že mezi pedagogy existuje v takto pojaté nominační úspěšnosti poměrně značná variabilita, kterou popisují i zahraniční studie (např. McBee, 2010). Důležité je také připomenout, že ani pedagog s největší mírou shody mezi vlastní nominací a testem CFT 20-R nebyl výrazně úspěšnější než jeho kolegové.

Zajímavé je, že míru shody mezi nominací a testem (at' už ho pojímáme jako externí objektivní kritérium či ho řadíme na stejnou úroveň jako nominaci učitele) neovlivňuje délka praxe pedagoga. Přitom někteří zahraniční autoři považují právě délku praxe za důležitou proměnnou nominačního i následného vzdělávacího procesu. Současně však podotýkají, že pedagogická praxe sama o sobě nemusí být dostatečnou zárukou přesné identifikace 
nadání, zvláště pokud není doplněna cíleným vzděláváním, zaměřeným na specifické charakteristiky a vzdělávací potřeby nadaných žáků (Kronborg \& Plunkett, 2013). V této souvislosti je proto třeba zmínit, že naši pedagogové se standardně rozvojových programů v této oblasti neúčastní, což mohlo ovlivnit vztah učitelské nominace a výsledků inteligenčního testu (Česká školní inspekce [ČŠI], 2016).

Požadavek seřadit nominované děti podle očekávané míry jejich potenciálního intelektového nadání jsme do našeho šetření zařadili nově, nebyl dle našich poznatků a dostupných empirických zdrojů v žádné nominační strategii použit. Ačkoliv pomohl objevit již zmíněný vztah mezi pořadím nominace a fluidní inteligencí, pro samotnou praktickou identifikaci nepovažujeme tento požadavek za př́liš funkční. Utvořením pořadí jsme totiž vystavili pedagogy požadavku velmi jemně diferencovat mezi schopnostmi a dovednostmi specifické skupiny žáků, které oni sami považují za nadané. Samotná nominace, tedy diferenciace takových žáků od běžných dětí, je sama o sobě náročným procesem, schopnost dále rozlišovat mezi těmito specifickými dětmi v pásmu nadprůměru je ještě obtížnějš́í. Díky tomuto požadavku proto mohlo dojít $\mathrm{k}$ určitým hypotetickým zkreslením, např́lklad upřednostněním osobnostních, sociálních, emočních či jiných charakteristik žáka při jeho umístění v nominační řadě.

Zajímavé také je, že pedagogové oproti testu CFT 20-R nominovali výrazně větší počet dětí (33 oproti 12), z celkového počtu 106 dětí tedy označili přibližně třetinu žáků. Nabízí se tedy otázka, zda by nebylo v př́ípadě realizace podobně zaměřeného výzkumu $\mathrm{v}$ budoucnu vhodné vymezit procento prevalence výskytu nadaných žáků $\mathrm{v}$ populaci, př́padně konkrétní hodnotu IQ, která se pro stanovení diagnózy a následných podpůrných opatření v PPP obvykle používá. Tato informace by mohla pomoci pedagogům lépe identifikační strategii zacílit. V tomto kontextu je však třeba upozornit na to, že nejen u nás, ale i mezi zahraničními odborníky probíhají již několik let diskuse o tom, kolik dětí a s jakou mírou schopností bychom měli mezi nadané zahrnovat. Naprŕklad Terman (1925) uvažoval o $1 \%$ z populace, Gagné (2005) hovoří o $10 \%$, Renzulli (2005) udává 15-20\% žákủ. Navíc je možné, že někteří pedagogové mohli uvažovat spíše o tradičním pojetí inteligence (ve smyslu vysokého IQ), jiní mohli upřednostnit spíše doménově specifický pohled a uvažovat o více dimenzích schopností nominovaných žáků (Sternberg \& Davidson, 2005; Subotnik et al., 2011). Bližší specifikace nominačního kritéria by tedy byla v podobně zaměřených budoucích výzkumech jistě žádoucí.

At' už jsou nominační strategie pedagogů jakékoli, odpověd' na hlavní výzkumnou otázku naší studie je poměrně jednoznačná. Ačkoliv určitý vztah mezi nominací pedagogů a výsledků testu fluidní inteligence existuje, obě formy skríningu vyhledávají do velké míry odlišné děti. Přitom právě skóry inteligenčních testů bývají obvykle považovány za objektivní kritérium 
mimořádného nadání, se kterým je učitelské hodnocení srovnáváno. Řada autorů (např. Gentry \& Mann, 2008; Renzulli \& Delcourt, 1986) však tento př́istup kritizuje. Dle nich a dalších studií (nap̌r. Foreman \& Gubbins, 2015) je učitelská nominace či hodnocení pomocí posuzovacích škál neocenitelným zdrojem informací o schopnostech dítěte, které nelze získat pouze z výsledků výkonových testů. S tímto pohledem souhlasí i autoři relativně nové metaanalýzy (Acar et al., 2016), kteří poukazují na to, že se množiny identifikovaných nadaných dětí pomocí učitelského hodnocení a výkonových testů prolínají jen částečně.

Acar, Sen a Cayirdagová (2016) proto doporučují nenahrazovat jeden přístup druhým, ale informace z obou forem identifikace kombinovat. Současně se nabízí otázka, zda v př́padě skríningu mimořádného nadání spoléhat pouze na jednodimenzionální test inteligence. Profil schopností žáků totiž nemusí být vždy vyrovnaný a test zaměřený na fluidní inteligenci tak může přehlédnout např. děti s nadprůměrnými verbálními schopnostmi. Kromě toho někteří žáci s vysokou úrovní fluidní inteligence mohou mít problémy s rychlostními úkoly (Reams et al., 1990) a mohou tedy selhávat v testech s časovým limitem (kam mimochodem spadá právě CFT 20-R).

Jako nejvhodnější se proto jeví během skríningové fáze identifikace nadaných žáků využít komplexnější postup, který zahrnuje jak hodnocení učitelem, tak výkonově zaměřené metody, které navíc testují více kognitivních schopností. Každý z dílčích komponentů tohoto systému by nominoval odlišnou množinu žáků. Efektivitu (respektive validitu) jednotlivých zdrojů nominace by navíc bylo vhodné dále ověřovat. Podle našeho názoru by však nemělo jít jen o běžně využívaný postup v podobě individuální diagnostiky komplexní inteligenční baterií, ale o ověrení prediktivní validity, tedy využití kritéria, který se vztahuje k účelu identifikace. Mohlo by jít tedy např. o zhodnocení úspěšnosti takových dětí v konkrétním vzdělávacím programu pro nadané žáky, či obecněji jejich pozdější úspěchy ve školním či pracovním životě (Renzulli \& Delcourt, 1986).

\section{Limity studie}

Ačkoli jsme se pokusili o co nejpřxesnější napodobení procesu nominace a identifikace intelektově nadaných žáků v českých školách, má prezentovaný postup i celá studie určité limity.

Hlavním deficitem je samotná uměle navozená situace procesu identifikace nadání a malý výzkumný soubor, který neumožňuje získané výsledky zobecňovat. V tomto smyslu chápeme výsledky spíše jako prvotní sondu do dané problematiky s tím, že se chceme danému tématu $\mathrm{v}$ budoucnu věnovat intenzivněji a zahrnout soubor rozsáhlejší i s případným využitím dat z reálného procesu identifikace např. ve spolupráci s PPP. 
Záměrná volba jediné školy pro tento výzkum byla vedena naší snahou realizovat simulaci celého procesu $\mathrm{v}$ rámci jednotně nastavených podmínek školy a jednotného způsobu vedení pedagogů. Tato př́ednost se však současně stává i deficitem studie, jelikož jsme nemohli zachytit celou šiři proměnných, které by bylo možné postihnout při zapojení většího počtu spíše odlišných škol z různých regionů, zejména pak pedagogů s různou osobní i vzdělávací zkušeností při práci s nadanou populací žáků. I toto omezení chceme řešit v následných výzkumech zapojením většího počtu škol.

\section{Finanční podpora}

Studie byla podpořena v rámci Specifického výzkumu MUNI/A/1137/2019 Fakulty sociálních studií Masarykovy univerzity.

\section{Literatura}

Acar, S., Sen, S., \& Cayirdag, N. (2016). Consistency of the performance and nonperformance methods in gifted identification: A multilevel meta-analytic review. Gifted Child Quarterly, 60(2), 81-101. https://doi.org/10.1177/0016986216634438

Baudson, T. G., \& Preckel, F. (2016). Teachers' conceptions of gifted and average-ability students on achievement-relevant dimensions. Gifted Child Quarterly, 60(3), 212-225. https:// doi.org/10.1177/0016986216647115

Benson, N. F., \& Kranzler, J. H. (2017). Another look at the construct validity of the gifted rating scales: Preschool/kindergarten and school forms. Journal of Psychoeducational Assessment, 36(8), 782-797. https://doi.org/10.1177/0734282917710377

Carman, C. A. (2011). Stereotypes of giftedness in current and future educators. Journal for the Education of the Gifted, 34(5), 790-812. https://doi.org/10.1177/0162353211417340

Cohen, J. (1960). A coefficient of agreement for nominal scales. Educational and Psychological Measurement, 20(1), 37-46. https://doi.org/10.1177/001316446002000104

Čavojská, M., \& Šedá, S. (2010). Vybledáváme rozumově nadané žáky, krok za krokem s nadaným žákem: Metodická príručka. Výzkumný ústav pedagogický.

Česká školní inspekce. (2016). Tematická zpráva - Vz̃dèláváni nadaných, talentovaných a mimorádnè nadaných dětí a žákỉ. ČŠI. https://www.csicr.cz/cz/Aktuality/Tematicka-zprava-Vzdelavani-nadanych,-talentovanych

Dai, D. Y. (2018). A history of giftedness: Paradigms and paradoxes. In S. I. Pfeiffer (Ed.), Handbook of giftedness in children. Psychoeducational theory, research, and best practices $\left(2^{\text {nd }}\right.$ ed., s. 1-14). Springer.

Demaray, M. K., \& Elliot, S. N. (1998). Teachers' judgments of students' academic functioning: A comparison of actual and predicted performances. School Psychology Quarterly, 13(1), 8-24. https://doi.org/10.1037/h0088969

Dočkal, V. (2016). Diagnostika nadania v teórii, vo výskume a v praxi. Svět nadání, 5(1), 12-22.

Endepohls-Ulpe, M., \& Ruf, H. (2006). Primary school teachers' criteria for the identification of gifted pupils. High Ability Studies, 16(2), 219-228. https://doi.org/10.1080/13598130600618140 
Fajmonová, V., Hönigová, S., Urbánek, T., \& Širůček, J. (2015). CFT 20-R - Cattelliov test fluidní inteligence. Hogrefe - Testcentrum.

Foreman, J. L., \& Gubbins, E. J. (2015). Teachers see what ability scores cannot: Predicting student performance with challenging mathematics. Journal of Advanced Academics, 26(1), 5-23. https://doi.org/10.1177/1932202X14552279

Freeman, J., \& Josepsson, B. (2002). A gifted programme in Iceland and its effects. High Ability Studies, 13(1), 35-46. https://doi.org/10.1080/13598130220132299

Gagné, F. (1994). Are teachers really poor talent detectors? Comments on Pegnato and Birch's (1959) study of the effectiveness and efficiency of various identification techniques. Gifted Child Quarterly, 38(3), 124-126. https://doi.org/10.1177/001698629403800305

Gagné, F. (2005). From gifts to talents: The DMGT as a developmental model. In R. J. Sternberg \& J. E. Davidson (Eds.), Conceptions of giftedness (2 ${ }^{\text {nd }}$ ed., s. 98-120). Cambridge University Press.

Gear, G. H. (1976). Accuracy of teacher judgment in identifying intellectually gifted children: A review of the literature. Gifted Child Quarterly, 20(4), 478-489. https://doi.org/ doi:10.1177/001698627602000416

Gentry, M., \& Mann, R. L. (2008). Total school cluster grouping \& differentiation: A comprehensive, research-based plan for raising student achievement \& improving teacher practices. Creative Learning Press.

Gross, M. U. M. (1997). Changing teacher attitudes towards gifted children: An early and essential step. In J. Chan, R. Li, \& J. Spinks (Eds.), Maximizing potential: Lengthening and strengthening our stride (s. 3-22). The University of Hong Kong Social Sciences Research Centre.

Hansen, J. B., \& Feldhusen, J. F. (1994). Comparison of trained and untrained teachers of gifted students. Gifted Child Quarterly, 38(3), 115-121. https://doi.org/10.1177/001698629403800304

Havigerová, J. M. (2013). Vybledáváni nadaných dètí v préelškolním věku: Škála charakteristik nadání a její adaptace na české podminky. Grada Publishing.

Havigerová, J. M., Haviger, J., \& Juklová, K. (2013). Škála charakteristik nadání pro předškolní děti - Shody a rozpory v posuzování nadání předškoláků mezi učitelkami MŠ a rodiči. e-Pedagogium, 13(3), 68-80. https://doi.org/10.5507/epd.2013.033

Hř́bková, L., Nejedlý, P., \& Zhouf, J. (2013). IDENA - Posuzovaci škály a didaktické testy k. vybledávání nadaných žákư. Národní ústav pro vzdělávání.

Hunsaker, S. L. (1994). Creativity as a characteristic of giftedness: Teachers see it, then they don't. Roeper Review, 17(1), 11-15. https://doi.org/10.1080/02783199409553610

Impara, J. C., \& Plake, B. S. (1998). Teachers' ability to estimate item difficulty: A test of assumptions in the Angoff standard setting method. Journal of Educational Measurement, 35(1), 69-81. https://doi.org/10.1111/j.1745-3984.1998.tb00528.x

Jabůrek, M. (2014). Přehled českých a zahraničních posuzovacích škál pro identifikaci nadání u dětí předškolního a školního věku. Svět nadání, 3(1), 18-36.

Jacobs, J. C. (1971). Effectiveness of teacher and parent identification of gifted children as a function of school level. Psychology in the Schools, 8(2), 140-142. https://doi.org/10.1002/15206807(197104)8:2<140::AID-PITS2310080210>3.0.CO;2-K

Johnson, A. B., Vickers, L., \& Price, R. (1995). Teaching gifted children: A summer institute for regular classroom teacher. Education, 105(2), 193-200.

Kaufman, S. B., Reynolds, M. R., Liu, X., Kaufman, A. S., \& McGrew, K. S. (2012). Are cognitive $g$ and academic achievement $g$ one and the same $g$ ? An exploration on the Woodcock-Johnson and Kaufman tests. Intelligence, 40(2), 123-138. https://doi.org/10.1016/j. intell.2012.01.009 
Kornmann, J., Zettler, I., Kammerer, Y., Gerjets, P., \& Trautwein, U. (2015). What characterizes children nominated as gifted by teachers? A closer consideration of working memory and intelligence. High Ability Studies, 26(1), 75-92. https://doi.org/10.1080/1359813 9.2015 .1033513

Kronborg, L., \& Plunkett, M. (2013). Responding to professional learning: How effective teachers differentiate teaching and learning strategies to engage highly able adolescents. Australasian Journal of Gifted Education, 22(2), 52-63.

Kvist, A. V., \& Gustafsson, J. E. (2008). The relation between fluid intelligence and the general factor as a function of cultural background: A test of Cattell's Investment theory. Intelligence, 36(5), 422-436. https://doi.org/10.1016/j.intell.2007.08.004

Machts, N., Kaiser, J., Schmidt, F. T. C., \& Möller, J. (2016). Accuracy of teachers' judgments of students' cognitive abilities: A meta-analysis. Educational Research Review, 19, 85-103. https://doi.org/10.1016/j.edurev.2016.06.003

Machů, E. (2010). Nadaný žák. Paido.

McBee, M. (2010). Examining the probability of identification for gifted programs for students in Georgia elementary schools: A multilevel path analysis study. Gifted Child Quarterly, 54(4), 283-297. https://doi.org/10.1177/0016986210377927

McClain, M. C., \& Pfeiffer, S. (2012). Identification of gifted students in the United States today: A look at state definitions, policies, and practices. Journal of Applied School Psychology, 28(1), 59-88. https://doi.org/10.1080/15377903.2012.643757

McCoach, D. B., \& Siegle, D. (2007). What predicts teachers' attitudes toward the gifted?. Gifted Child Quarterly, 51(3), 246-254. https://doi.org/10.1177/0016986207302719

Mönks, F. J., \& Katzko, M. W. (2005). Giftedness and gifted education. In R. J. Sternberg \& J. E. Davidson (Eds.), Conceptions of giftedness (2 ${ }^{\text {nd }}$ ed., s. 187-201). Cambridge University Press.

Národní ústav pro vzdělávání. (2018). Standard komplexni diagnostiky mimorádného (intelektového) nadání. http://www.nuv.cz/uploads/rovne_prilezitosti_ve_vzdelavani/nadani/diagnostika/ standard_diagnostiky_mn_2018_12_06.pdf

National Association for Gifted Children. (2015). 2014-2015 - State of the States in gifted education: Policy and practice data. NAGC. http://www.nagc.org/sites/default/files/key\%20reports $/ 2014-2015 \% 20$ State $\% 20$ of $\% 20$ the $\% 20$ States $\% 20 \% 28$ final $\% 29$.pdf

Neumeister, K. L. S., Adams, C. M., Pierce, R. L., Cassady, J. C., \& Dixon, F. A. (2007). Fourth-grade teachers' perceptions of giftedness: Implications for identifying and serving diverse gifted students. Journal for the Education of the Gifted, 30(4), 479-499. https://doi. org/10.4219/jeg-2007-503

Pegnato, C. W., \& Birch, J. W. (1959). Locating gifted children in junior high schools a comparison of methods. Exceptional Children, 25(7), 300-304. https://doi. org/10.1177/001440295902500702

Pfeiffer, S. I. (2001). Professional psychology and the gifted: Emerging practice opportunities. Professional Psychology: Research and Practice, 32(2), 175-180. https://doi.org/10.1037/07357028.32.2.175

Portešová, Š., Budíková, M., \& Koutková, H. (2008). Postoje českých učitelů ke vzdělávání mimořádně nadaných žáků. Psychologia a patopsychologia diet’ata, 42(3) 229-251.

Reams, R., Chamrad, D., \& Robinson, N. M. (1990). The race is not necessarily to the swift: Validity of WISC-R bonus points for speed. Gifted Child Quarterly, 34(3), 108-110. https:// doi.org/10.1177/001698629003400304 
Renzulli, J. S. (2005). The three-ring definition of giftedness: A developmental model for promoting creative productivity. In R. J. Sternberg \& J. E. Davidson (Eds.), Conceptions of giftedness ( $2^{\text {nd }}$ ed., s. 246-280). Cambridge University Press.

Renzulli, J. S., \& Delcourt, M. (1986). The legacy and logic of research on the identification of gifted persons. Gifted ChildQuarterly, 30(1), 20-33. https://doi.org/10.1177/001698628603000104

Renzulli, J. S., Smith, L. H., White, A. J., Callahan, C. M., Hartman, R. K., \& Westberg, K. L. (1997). Scales for rating the behavioral characteristics of superior students. Creative Learning Press.

Rost, D. H., \& Hanses, P. (1997). Wer nichts leistet, ist nicht begabt? Zur Identifikation hochbegabter Underachiever durch Lehrkräfte. Zeitschrift für Entwicklungspsychologie und Pädagogische Psychologie, 29(2), 167-177.

Rothenbusch, S., Voss, T., Golle, J., \& Zettler, I. (2018). Linking teacher and parent ratings of teacher-nominated gifted elementary school students to each other and to school grades. Gifted Cbild Quarterly, 62(2), 230-250. https://doi.org/10.1177/0016986217752100

Schneider, W. J., \& McGrew, K. S. (2018). The cattell-horn-carroll theory of cognitive abilities. In D. P. Flanagan \& E. M. McDonough (Eds.), Contemporary intellectual assessment: Theories, tests, and issues (4th ed., s. 73-163). The Guilford Press.

Siegle, D. (2001). Overcoming bias in gifted and talented referrals. Gifted and Talented Communicator, 32(3), 22-25.

Siegle, D., \& Powell, T. (2004). Exploring teacher biases when nominating students for gifted programs. Gifted Child Quarterly, 48(1), 21-29. https://doi.org/10.1177/001698620404800103

Silverman, L. K. (1993). Characteristics of giftedness scale. Gifted Development Center.

Silverman, L. K. (2009). The measurement of giftedness. In L. V. Shavinina (Ed.), International handbook on giftedness (s. 947-970). Springer.

Sternberg, R. J., \& Davidson, J. (Eds.). (2005). Conceptions of giftedness (2 ${ }^{\text {nd }}$ ed.). Cambridge University Press.

Sternberg, R. J., \& Kaufman, S. B. (2018). Theories and conceptions of giftedness. In S. I. Pfeiffer (Ed.), Handbook of giftedness in children: Psychoeducational theory, research, and best practices $\left(2^{\text {nd }}\right.$ ed., s. 29-47). Springer.

Subotnik, R. F., Olszewski-Kubilius, P., \& Worrell, F. C. (2011). Rethinking giftedness and gifted education: A proposed direction forward based on psychological science. Psychological Science in the Public Interest, 12(1), 3-54. https://doi.org/10.1177/1529100611418056

Südkamp, A., Kaiser, J., \& Möller, J. (2012). Accuracy of teachers' judgments of students' academic achievement: A meta-analysis. Journal of Educational Psychology, 104(3), 743-762. https://doi.org/10.1037/a0027627

Tannenbaum, A. J. (1986). Giftedness: A psychosocial approach. In R. J. Sternberg \& J. E. Davidson (Eds.), Conceptions of giftedness (s. 21-252). Cambridge University Press.

Terman, L. M. (1925). Genetic studies of genius: Vol. 1. Mental and physical traits of a thousand gifted children. Stanford University Press.

VandenBos, G. (2007). APA dictionary of psychology. American Psychological Association.

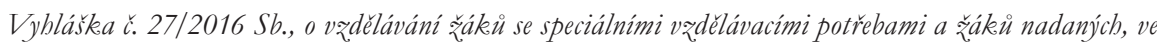
znèni účinném od 1. 1. 2018. (2018). http://www.msmt.cz/dokumenty-3/vyhlaska-c-27-2016sb-o-vzdelavani-zaku-se-specialnimi-2

Worrell, F. C., \& Erwin, J. O. (2011). Best practices in identifying students for gifted and talented education programs. Journal of Applied School Psychology, 27(4), 319-340. https://doi. org/10.1080/15377903.2011.615817 


\section{Kontakt na autory}

\section{Šárka Portešová}

Institut výzkumu dětí, mládeže a rodiny, Fakulta sociálních studií, Masarykova univerzita E-mail: portes@fss.muni.cz

Michal Jabůrek

Institut výzkumu dětí, mládeže a rodiny, Fakulta sociálních studí, Masarykova univerzita E-mail: michal.jaburek@gmail.com

Martin Tancoš

Katedra psychologie, Fakulta sociálních studií, Masarykova univerzita

E-mail: 446083@mail.muni.cz

Edita Chvojková

Institut výzkumu dětí, mládeže a rodiny, Fakulta sociálních studií, Masarykova univerzita E-mail: edita.chvojkova@mail.muni.cz

Simona Válková

Studentka doplňujícího studia výchovného poradenství, Pedagogická fakulta, Masarykova univerzita

E-mail:477580@mail.muni.cz

\section{Corresponding authors}

\section{Šárka Portešová}

Institute for Research of Children, Youth and Family, Faculty of Social Studies, Masaryk University

E-mail: portes@fss.muni.cz

Michal Jabůrek

Institute for Research of Children, Youth and Family, Faculty of Social Studies, Masaryk University

E-mail: michal.jaburek@gmail.com

\section{Martin Tancoš}

Department of Psychology, Faculty of Social Studies, Masaryk University

E-mail:446083@mail.muni.cz

\section{Edita Chvojková}

Institute for Research of Children, Youth and Family, Faculty of Social Studies, Masaryk University

E-mail: edita.chvojkova@mail.muni.cz

Simona Válková

Student of lifelong learning programme Educational Guidance, Faculty of Education, Masaryk University

E-mail:477580@mail.muni.cz 
